\title{
Relationship between M. leprae and BCG on the Skin Reaction (I st Report)
}

\author{
Results on the skin reactions in sensitized \\ guinea pigs
}

\author{
Michiaki MAEDA aNd KazUnaRi NAKAMUUA
}

(National Institute for Leprosy Research)

Relationship between the tuberculin reaction and the reaction to Dharmendra's antigen have been investigated in peoples contained all population, and it was recognized that these relation of both reactions were different each other in the examined towns or villages. Therefore, the relationship between $M$. leprae and M. tuberculosis or BCG related to tuberculin reaction was studied on the skin test in experimental animals.

The reaction to Dharmendra's antigen was compared with the reaction to old tuberculin or PPD-s prepared from $M$. tuberculosis hominis and the reaction to Mitsuda's antigen was compared with the reaction to the heat-killed tubercle bacilli suspension with tissue prepared from healthy persons in guinea pigs sensitized by the heat-killed tubercle bacilli or BCG with adjuvant.

The averaged sizes of reactions to old tuberculin, PPD-s or the heat-killed tubercle bacilli suspension with tissue were about equal each other in both sensitized guinea pigs, but the averaged sizes of reactions to Dharmendra's or Mitsuda's antigens in BCG-sensitized animals were larger than the sizes of both reactions in animals sensitized by tubercle bacilli. From these results, it seems that the common antigen contained in $M$. leprae and BCG is more than that contained in M. leprae and M. tuberculosis.

The size of reaction to Mitsuda's antigen and the heat-killed mycobacteria suspension with tissue in healthy or sensitized guinea pigs were investigated for four weeks after the injection of antigen. The largest size of reaction was seen at $24 \mathrm{hrs}$. after the injection of antigen and the size of reaction at $5 \sim 28$ days was smaller than that at $1 \sim 3$ days after the injection of antigen. Therefore, the phenomenon of "preexistence hypersensitivity" explained by Wade was not observed in these animal experiments. 


\title{
皮内反応からみたらい菌とBCGとの関連性
}

\author{
第 1 報 感作モルモットにおける反応
}

前田道明・中 村 一 成

(国立多摩研究所)

（受付 1965 年 9 月 11 日）

さきに柳沢らは，人型結核菌或は BCG による感作も ルモットにおいては, ツベルクリン反応（ツ反応之略 す）が陽性を示すとレプロミン反応（レ反応と略す）す 陽性を示してくることを知り, 健康者についてッ反応と ダルメンドラ抗原による反応（D反応と略す）とを試み たところ，らい喼者の場命と異り両反応は高い相関にあ るととを報告した”。同じ顷から数力所の町村住民につ いてッ反応とD反応との関連性について調查を続けてい たが，一部の地域の住民では両反応の相関がかなり低い ことを知った。この両反応の相関における地域差の起る 原因を種々の何度から追究したところ， BCG 接種の既 往がかなり大きな役割を占めているように思われた22。 従って人型結核菌と BCG とによる感作動物についてッ 反応と D反応との関係を検討した。

\section{実験方法および成績 \\ 実 験 I}

方法 : Römer 反応除性の白他モルモット（体重平均 $350 \mathrm{~g}) 30$ 匹を 2 群にわけ，1群には人型結核菌青山B株 の死菌 $0.2 \mathrm{mg}$, 他の 1 群には BCG 死菌 $0.2 \mathrm{mg}$, 流 動パラフィンを Adjuvant として左下肢筋肉内に注射し た。感作後 8 週目には人型結核菌由来の2000倍旧ツベル クリンとD抗原とにより，感作後11および18週目には人 型菌由来の精製ツ PPD-s $0.15 \gamma$ と D 抗原とによって皮 内反応試験を行い，抗原注射後 24 および 48 時䦥に判定を 行った。

成績：感作後 8,11 および18週目における各抗原によ る反応の平均硬結值は，表 1 に示す如くである。いずれ

Table 1. The averaged size $(\mathrm{mm})$ of induration of the skin reaction in two groups of the sensitized guinea pigs (Experiment I)

\begin{tabular}{|c|c|c|c|c|c|}
\hline \multirow{2}{*}{$\begin{array}{l}\text { Test-time } \\
\text { (Weeks after } \\
\text { sensitization) }\end{array}$} & \multirow{2}{*}{$\begin{array}{l}\text { Sensitized } \\
\text { animal-group }\end{array}$} & \multicolumn{2}{|c|}{ Reading at $24 \mathrm{hrs}$. } & \multicolumn{2}{|c|}{ Reading at $48 \mathrm{hrs}$. } \\
\hline & & Tuberculi & armendra & Tuberculin & Dharmendra \\
\hline \multirow{2}{*}{8 weeks } & Tubercle bacilli & 9.6 & 11.0 & 6.3 & 7.8 \\
\hline & B C G & 9.6 & 15.1 & 6.2 & 10.6 \\
\hline \multirow{2}{*}{11 weeks } & Tubercle bacilli & 13. 7 & 15.0 & 10.8 & 10.4 \\
\hline & $\mathrm{B} \mathrm{C} \mathrm{G}$ & 13.2 & 17. 0 & 10.2 & 10.9 \\
\hline \multirow{2}{*}{18 weeks } & Tubercle bacilli & 14.6 & 16.2 & 9.7 & 9.9 \\
\hline & B C G & 14.6 & 17.9 & 11.1 & 12.3 \\
\hline
\end{tabular}

Note : The old tuberculin $(1: 2,000)$ was used at 8 weeks and PPD-s in the concentration of $0.15 \gamma$ per $0.1 \mathrm{ml}$ at 11 or 18 weeks.

の検查時においても，また24時間值のみでなく48時間値 においても, 両感作動物群におけるッ反応の大きさがほ ぼ等しい場合には，D反応の大きさは常に人型結核菌感 作動物群よりも BCG 感作動物群の方が大きかった。

\section{実 験 II}

万法 : $\mathrm{R}_{\text {ömer }}$ 反応陰性の白包モルモット（体重平均 150g）40匹を 2 群にわけ，1群には人型結核菌青山B株 
の死菌 $1 \mathrm{mg}$ ，他の 1 群には BCG 死藏 $1 \mathrm{mg}$ ，流動 パラフィンを Adjuvant として左下抆筋闪内に注射し た。感作後 5 週目には人型藏币来の䊑製ツ PPD-s $0.15 \gamma$ とD抗原とにより度内反応を行った。また感作後 9 週目 にはレ反応㭘査に D 抗原の外に光田抗原をむ用い，ま たツ反応の代りに健康人皮虔組織乳剂に人型結核菌を $0.01 \mathrm{mg} / \mathrm{ml}$ の割命に加え加熱殺菌したもの（組織乳剂 加人型結核死菌浮遊液）と，BCG を同量加えて加熱殺
藏したもの（組織乳剂加BCG死菌浮遊液）とを用いた。

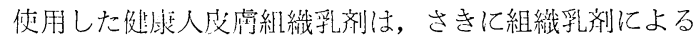
非特異必忍を检查したときに䏫たもの ${ }^{3)}$ と同一のもの

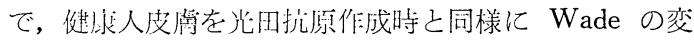
法4)に従って処理したものである。てれら4抗原による 皮内反応成績は，抗原注射後 $1 ， 2 ， 5 ， 7 ， 10 １ 4$ 日 目にそれぞれ判定した。

成績 : 感作後 5 週目におけるツ反応とD反応との関係

Table 2. The averaged size $(\mathrm{mm})$ of induration of the skin reaction at 5 weeks in both sensitized guinea pigs (Experiment II)

\begin{tabular}{c|cc|cc}
\hline \multirow{2}{*}{$\begin{array}{c}\text { Sensitized } \\
\text { animal-group }\end{array}$} & \multicolumn{2}{c|}{ Reading at 24 hrs. } & \multicolumn{2}{c}{ Reading at 48 hrs } \\
\cline { 2 - 4 } & Tuberculin & Dharmendra & Tuberculin & Dharmendra \\
\hline Tubercle bacilli & 14.9 & 10.0 & 9.8 & 6.7 \\
B C G & 15.6 & 12.3 & 10.6 & 7.2 \\
\hline
\end{tabular}

Note : PPD-s was used for the tuberculin test.

Fig. 1. The size of reaction at $1 \sim 14$ days in healthy and sensitized guinea pigs
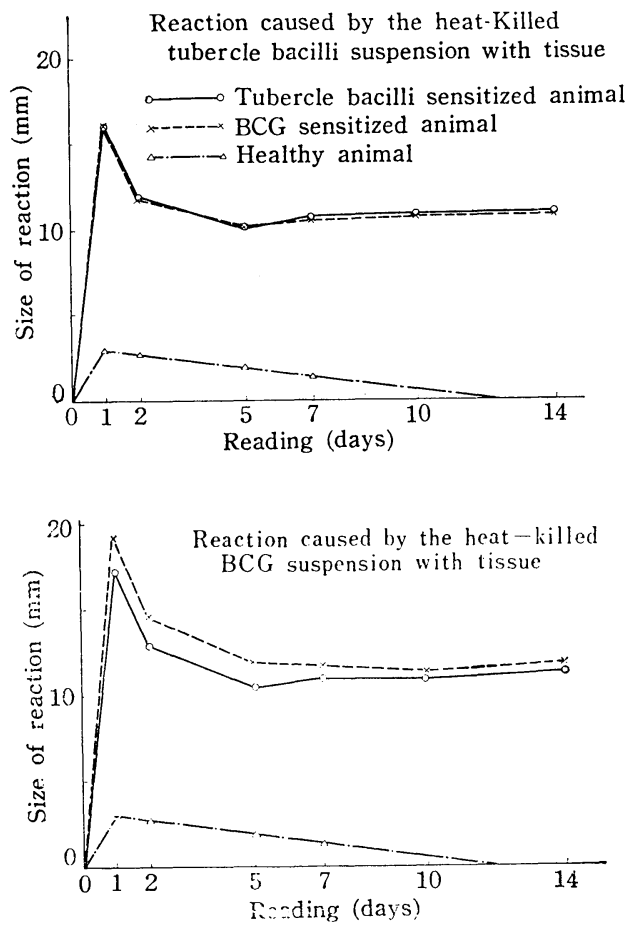

は，表 2 に示す如くである。实験Ｉにみられた成績の如 く, ツ反応の大きさに比し，D応では明らかに人型結
Fig. 2. The size of reaction at $1 \sim 14$ days in healthy and sensitized guinea pigs
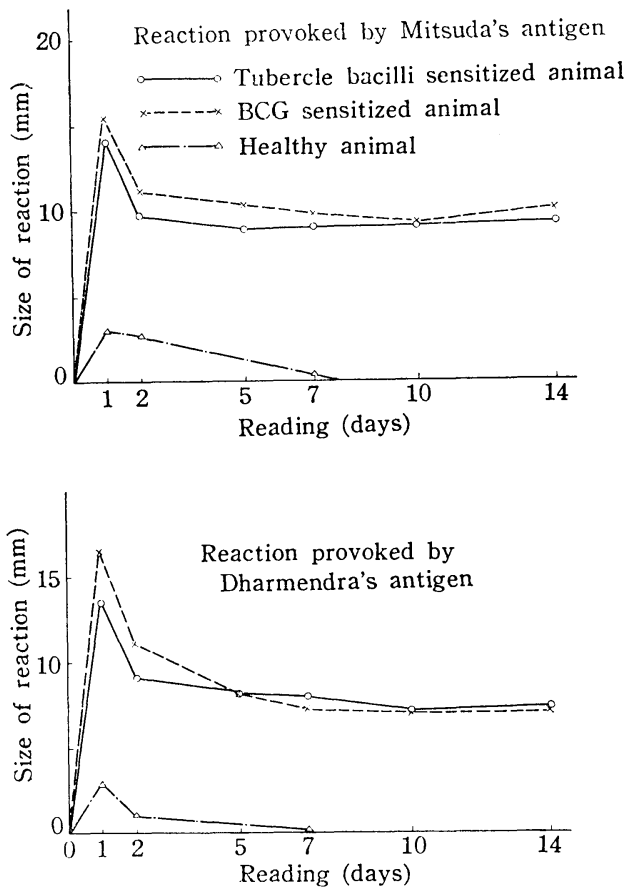

核菌感作動物よりも BCG 感作動物の方が大きい反応値 を示していた。

次に，感作:後 9 週目における侈抗原による反心の硬絬 
值の時閒的推移を雨感作動物間で比較すると, 図 1,2 の如くである。組織乳剂扣 BCG 死菌浮遊液による反応 では，全般的にみて人型結核菌感作群よりも BCG 感作 群の方が大きい反応性を示している。ての事笑は組織乳 剂加 BCG 死菌浮遊液の BCG に対する型特異性を示す ものである。しかし, 組織乳剂加人型結核死菌浮·遊液に よる反応では両感作動物間に反応值の差は認められなか
ったが，光田抗原およびD抗原による反応では，いずれ も BCG 感作動物における反応值か人型結核菌感作動物 における反応优よりも大きかった。すなわち，表 3 に示 すように, 死菌浮遊液による反応に执いても, ツベルク リンによる反応の場合と同様に, BCG 感作動物におい ては人型結核菌感作動物におけるよりも大きい反応值を 示していた。

Table. 3 The averaged size $(\mathrm{mm})$ of the skin reaction at 9 weeks in both sensitized guinea pigs (Experiment II)

\begin{tabular}{|c|c|c|c|c|}
\hline Reading & $\begin{array}{l}\text { Sensitized } \\
\text { animalgroup }\end{array}$ & $\begin{array}{l}\text { Killed tubercle bacilli } \\
\text { suspension with tissue }\end{array}$ & Mitsuda & Dharmendra \\
\hline \multirow{2}{*}{$24 \mathrm{hrs}}$. & Tubercle bacilli & 16. 10 & 13.95 & 13.63 \\
\hline & B C G & 16.10 & 15.38 & 16.45 \\
\hline \multirow{2}{*}{48 hrs. } & Tubercle bacilli & 11.85 & 9.65 & 9.15 \\
\hline & $\mathrm{B} C \mathrm{G}$ & 11.83 & 11.05 & 11.10 \\
\hline
\end{tabular}

各抁原による反応值の時蔺的推移をみると, 図 1,2 の如く, いずれの感作動物でも抗原注射後24㭙閌目に最 高値を示し，48特間目には急に減弱し，5日目以後は反 応値の減驹程度が極めて翑く, 14 日目であ組織乳剂加人 型結核菌或は BCG の死菌浮遊淮による反応では 10〜 $12 \mathrm{~mm}$, 光目抗原では $9 \sim 10 \mathrm{~mm}, \mathrm{D}$ 抗原では $7 \sim 8 \mathrm{~mm}$ を示していた。そして 4 週目における反応优は，いずれ の抗原でも $7 \mathrm{~mm}$ 以下の便結を示すにすぎなかった。こ

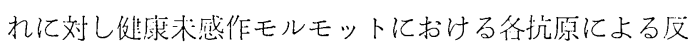
応では, 図 1,2 の如く, 24时䦌值では約 $3 \mathrm{~mm}$ の硬結 を示したが，48洔閌目以後は反応が減弱し，光田抗原お よびD捻原による反応では注射後 7 日日には殆んど硬結 を触知しえず，また組織乳剂加人型結核菌或は BCG 死 菌浮遊液による反応では 7 日目に $1.4 \mathrm{~mm}$ 在示し， 2 週 目以後はいずれの抗原によっても反応は認められなかっ た。すなわち, 未感作モルモットのみでなく, 人型結核 菌或はBCG の感作モルモットにおいても，抗原注射後 4 週目に24或は48侍閒に認められた反応优よりも大きな 反応を涩めることは出来なかった。

\section{考按}

健康人におけるッ反応とレ反応との閒にはかなり高い 相関が認められることは既に礕告したが11, 健尿人の中 でも地域によっては両反応间の相関の低いととろがみら れた。この地域差のみられる原因が住民が污染されてい る抗酸菌のうち人型結核菌と BCG とに関係が深いよう
に考えられたので，モルモットに打ける热礎実験を行っ た。

動物試験で人型結核菌或は BCG とらい菌との 関連性 を皮内反応の画加研究する直接的な方法としては，ら い菌による感作動物について人型藏由来のツベルクリン と BCG 由来のツベルクリンとによる反応を比較するこ とであるが，モルモットをらい菌で感作する柳沢らの方 法5,6) は大量の菌を必要とするので困暯であるため, 本 研究には問接的な方法を用いた。すなわち，人型結核菌 青山B怢抢よび BCG の死菌感作モルモットについて, 人型結㤥菌由来の旧ツベルクリン或は予研製 PPD-s と $\mathrm{D}$ 抗原とによる反応との此較を行った。その結果, 矢 験 I，II いずれの成績でも，両感作動物における人型結 核菌由来のツ反応值がほぼ等しい場合に，D抗原による 反応值は人型結㤥菌感作動物样よりも BCG 感作動物群 の方が大きかった。こしてての成續は, 死菌感作後 5 〜 18 週のいずれの検查においても，また 24 洔閐判定值の みでなく48特閉判定值においても認められた。従って, 極めて共通抗原の壦の多い人型結核菌とBCG とをらい 菌との関逨性でみると, らい菌は人型結核菌よりも BCG に共通抗原の場を多くもっていると言いえよう。柳沢ら がさきに報告した1，5）感作モルモットにおけるッ反応と レ反応との関係をかかる観点で比較してみると，数匹ず つの試験成績にすぎないが，われわれの上述の成績と同 じ傾向にあることが窥われた。

光四抗原はらい患者の組織およびその成分とらい菌と 
が混在している抗原である。そこで水溶性抗原であるッ ベルクリンの代りに, 光田抗原と同一条件にある人型結 核菌或は BCG 由来の抗原を作るために, さきに組織乳 剂による皮内反応検査時に用いた健康人の皮膚組織乳 剂3) に人型結核菌および BCG の生菌 $0.01 \mathrm{mg}$ ずつを加 え, 高圧殺菌した組織乳剂加死菌浮遊液を用いた。そし て人型結核菌および BCG の感作動物について, 光田抗 原および死菌浮遊液による反応との比較を試みた。その 結果, 組織乳剂加人型結核死菌浮遊液による反応值は両 感作動物群間で大差がみられないが, 光田抗原およびD 抗原による反応では BCG 感作動物の方が人型結核菌感 作動物よりも大きな反応值を示していた。乙の現象は, 組織乳剂加抗酸菌浮遊液による検查においても, らい菌 は人型結核菌よりも BCG により多くの共通抗原を有す るととを示唆していよう。

さて人型結核菌或は BCG の死菌感作動物における 4 種の抗原による皮内反応の硬結倬を抗原注射後 4 週目ま で観祭した垁験II の成績では，さきに柳沢らが報告した 成績 1) とやや異る興味ある成績がみられた。

4 抗原による反応はいずれも 24 時間值が 最大值であ り，その後急に反応は減弱し，5 日以後 14 日までの反応 值では余り変動がなく，4週目に至ってもかなりの硬結 值を示していた。すなわち, 光田抗原による反応では, $1 \sim 2$ 週には $9 \sim 10 \mathrm{~mm}, 4$ 週目には $7 \mathrm{~mm}$ であり,ま た光田抗原と同一条件で作られた組織乳剂加人型結核菌 或は BCG の死菌浮遊液による反応でも，1〜2週には 10.5〜12mm, 4 週目には $6 〜 7 \mathrm{~mm}$ の硬結を認めた。 これに対し, 組織を含まない死菌浮遊液，D抗原による 反応では，1〜2週には $7 \sim 8 \mathrm{~mm}, 4$ 週目には 2 $3 \mathrm{~mm}$ の硬結を認めたにすぎず，組織乳剂を含む抗原に よる反応值よりも小さかった. しかし，いずれの抗原に よる反応でも, 抗原注射後 $2 \sim 4$ 週目において 24 時間值 に匹適する反応を認めることは出来なかった。

次に, 未感作健康モルモットに打ける 4 種の抗原によ る皮内反応成績を時間的に観祭すると, いずれの抗原に よる反応でも 24 時間值が最高 $3 \mathrm{~mm}$ で, その後減弱し, 光田抗原およびD抗原による反応は 1 週目には殆んど消 失し, 組織乳剂加人型結核菌或は $\mathrm{BCG}$ 死菌浮遊液によ る反応は10日目頃に殆んど消失していた。そして抗原注 射後 2 週以後には殆んど皮内反応を認めることは出来な かった。Wade 4) は, 光田抗原による反応は preexistence hypersensitivity を示すむのであるから，人体では早期 反応で判定するよりも晚期反応でみるべきことを提唱 し, 多くの研究者がこの考え方を支持している。かかる
現象が人体で認められるならば，動物での皮内反応では 如何であろうか。

光田抗原や本研究に用いた組織乳剂加絬核菌或は $\mathrm{BC}$ G の死菌浮遊液は一種の vaccine と考えうるので， か かる抗原の皮内注射によって動物は感作されることはわ れわれがすでに報告した7)。しかし未感作モルモットお よび結核菌或は BCG の感作モルモットでしらべた本報 での成績では，抗原注射後 4 週目までにはその抗原によ って感作されているに拘らず，感作時に注射された抗原 によって感作された証拠を示す反応性は認められず，い ずれの反応值も抗原注射後 5 日目以後には徐々に小さく なっていた。但し，第 1 回目注射後 4 週目にかかる抗原 を再注射すると，乙の注射抗原に対して感作程度に合致 した皮膚反応の大きさを示してくることは報告した7)通 りである。従って, Wade が述べる如き現象は動物では 証明することは出来なかった。

\section{結 論}

ツ反応とD抗原による皮内反応との関係を一般住民に ついて調查すると, 雨老の関速性は地域によって差のあ るととが涩められた。そこで, ッ反応に関係の深い人型 絬核菌および BCG とらい菌との関係を，動物における 皮内反応によってしらべた。

人型結核菌或は BCG の死菌によって感作したモルモ ットに㧍いて，人型結核菌由来の旧ツベルクリン或は PPD-s とD抗原とによる反応の比較, 或は組織乳剂加 人型結核死菌浮遊液と光用抗原とによる反応の比較を行 った。その結果, 両感作動物におけるッ反応の大きさ或 は組織乳剂加人型結核死菌浮遊液による反応の大きさは ほぼ等しいにも拘らず，D抗原或は光田抗原による反応 の大きさは，人型結核菌感作動物におけるよりも BCG 感作動物における方が大きかった。従って，らい菌は人 型結核菌よりも BCG により多くの共通抗原を有するも の亡考える。

また本研究において，感作動物および健康動物におけ る光田抗原或は組織乳剂加結核死菌浮游液による反応値 を，抗原注射後 4 週目まで観察した。その結果，抗原注 射後 5 日以後の反応値には24〜 48時間値よりも大きな反 応はみられず，動物における反応は 24 時閒值を最高と し，その後は減弱するのみで，Wade が提唱している preexistence hypersensitivity を思わせる現象は認められ なかった。 
文献

1）柳沢謙・他：レプラ, 24:353（昭30）

2）前田道明・他：結核, $40: 307,351$ (昭40)

3) 前田道明・他：レプラ, 33:7（昭39）

4) WHO Expert Committee on Leprosy, 2 nd Report.
WHO Technical Report Series, No. 189 (1958)

5 ）柳沢謙・他：レプラ，25：192（㖊31）

6 ）柳沢諳：胸部疾患，3:151（昭34）

7）前田道明・他：レプラ，34：250（昭40）

(日本らい学会総会発表) 